\title{
Evaluation of surfactin synthesis in a genome reduced Bacillus subtilis strain
}

\author{
Mareen Geissler ${ }^{1}$, Ines Kühle ${ }^{1}$, Kambiz Morabbi Heravi ${ }^{1}$, Josef Altenbuchner ${ }^{2}$, Marius Henkel ${ }^{1 *}$ (i) \\ and Rudolf Hausmann ${ }^{1}$
}

\begin{abstract}
Strain engineering is often a method of choice towards increasing the yields of the biosurfactant surfactin which is naturally synthesized by many Bacillus spp., most notably Bacillus subtilis. In the current study, a genome reduced B. subtilis 168 strain lacking $10 \%$ of the genome was established and tested for its suitability to synthesize surfactin under aerobic and anaerobic conditions at $25^{\circ} \mathrm{C}, 30^{\circ} \mathrm{C}, 37^{\circ} \mathrm{C}$ and $40^{\circ} \mathrm{C}$. This genome reduced strain was named IIG-Bs20-5-1 and lacks, amongst others, genes synthesizing the lipopeptide plipastatin, the antibiotic bacilysin, toxins and prophages, as well as genes involved in sporulation. Amongst all temperatures tested, $37^{\circ} \mathrm{C}$ was overall superior. In comparison to the reference strain JABs24, a surfactin synthesizing variant of B. subtilis 168, strain IIG-Bs20-5-1 was both aerobically and anaerobically superior with respect to specific growth rates $\mu$ and yields $Y_{x / s}$. However, in terms of surfactin production, strain JABs24 reached higher absolute concentrations with up to $1147.03 \mathrm{mg} / \mathrm{L}$ and $296.37 \mathrm{mg} / \mathrm{L}$ under aerobic and anaerobic conditions, respectively. Concomitant, strain JABs24 reached higher $Y_{P / S}$ and $Y_{P / X}$. Here, an outstanding $Y_{P / X}$ of $1.541 \mathrm{~g} / \mathrm{g}$ was obtained under anaerobic conditions at $37^{\circ} \mathrm{C}$. The current study indicates that the employed genome reduced strain IIG-Bs20-5-1 has several advantages over the strain JABs24 such as better conversion from glucose into biomass and higher growth rates. However, regarding surfactin synthesis and yields, the strain was overall inferior at the investigated temperatures and oxygen conditions. Further studies addressing process development and strain engineering should be performed combining the current observed advantages of the genome reduced strain to increase the surfactin yields and to construct a tailor-made genome reduced strain to realize the theoretically expected advantages of such genome reduced strains.
\end{abstract}

Keywords: Lipopeptide, Biosurfactant, Strain development, Genome reduction, Anaerobic

\section{Introduction}

Bacillus subtilis is commonly denoted the model Grampositive bacterium. Due to its inherent characteristics, such as the natural secretion of proteases, high titers and low toxic by-product formation, this microorganism is an established bacterial platform for a variety of industrial applications (van Dijl and Hecker 2013). Amongst others, processes with B. subtilis as industrial host for the synthesis of proteases and riboflavin are implemented (Singh et al. 2017). Another promising metabolite is the biosurfactant surfactin, which is a cyclic lipopeptide

\footnotetext{
*Correspondence: marius.henkel@uni-hohenheim.de

${ }^{1}$ Department of Bioprocess Engineering (150k), Institute of Food Science and Biotechnology (150), University of Hohenheim, Fruwirthstr. 12, 70599 Stuttgart, Germany

Full list of author information is available at the end of the article
}

synthesized by Bacillus spp. Surfactin is attributed with a variety of characteristics. These properties, ranging from exceptional surface-activity and broad spectrum physico-chemical properties, as well as antimicrobial effects, make surfactin an interesting candidate for a variety of applications such as in the agricultural, detergent and food industry (Geissler et al. 2019). However, up to date, neither a strain nor a process was described having the potential of large-scale high-titer production of surfactin as the main target product. Past research in order to increase the yields can be divided in three groups, namely (i) optimization of medium and process parameter (Freitas de Oliveira et al. 2013; Gudiña et al. 2015), (ii) applying diverse process strategies (Coutte et al. 2013; Alonso and Martin 2016) and (iii) performing strain engineering (Coutte et al. 2015; Willenbacher et al. 2016). 
The complete sequence of the B. subtilis strain 168 genome, which comprises 4100 protein-encoding genes, was revealed by Kunst et al. (1997) and Barbe et al. (2009) resequenced this genome. Kobayashi et al. (2003) expanded the first sequence by determining essential genes in B. subtilis needed to sustain bacterial life. This laid the foundation of creating minimal genome cells (MGC) for Bacillus. MGC are defined as cells with a minimal gene set able to sustain life in the unlimited presence of nutrients and in the absence of environmental stress (Koonin 2000). Ideally, a genome reduced strain is expected to have a similar growth behavior and to yield higher product titers as the cells need less energy for genome replication, and dispensable proteins do not have to be transcribed and translated (Choe et al. 2016).

A B. subtilis strain derived from strain 168 with a genome reduction of $7.7 \%$ was engineered by Westers (2003). The strain lacked genes encoding for prophages as well as AT-rich islands. Under laboratory conditions, the reduction did not affect growth and viability. With respect to the heterologous production of a model protein, a positive effect of the genome reduction was not observed, and authors assumed that a redirection of energy resources into product formation did not occur. Also Ara et al. (2007) applied genome reduction to $B$. subtilis 168 in order to create a strain for the effective production of alkaline cellulase. The genome of the final strain MG1M was $0.99 \mathrm{Mb}$ smaller than its parental strain and the strain showed a similar growth behavior. However, cellulase and protease activity were similar to the parental strain 168 and consequently the product titer was not increased by genome reduction. Within the same group, another genome reduced strain missing $0.87 \mathrm{Mb}$ was created (Morimoto et al. 2008) and this strain was reported to have an improved extracellular and protease productivity from transformed plasmids carrying the respective genes.

Strain 168 is well-suited to employ strain engineering and was hence also used in this study as initial strain. However, strain 168 is only able to synthesize surfactin after the correction of the frameshift mutation in $s f p$ (Julkowska et al. 2005; Coutte et al. 2010). To allow for better evaluation of the performed genome reduction, strain 168 with a functional $s f p^{+}$was used as reference. The employed genome reduced strain within this study also carries a functional $s f p$ gene and the genome is $\sim 10 \%$ smaller. Amongst others, genes encoding for plipastatin, bacylisin, toxins and prophages, as well as genes involved in sporulation, were deleted markerless by Wenzel and Altenbuchner (2015). The type-strain B. subtilis DSM $10^{\mathrm{T}}$ was furthermore used as additional reference strain. Strain DSM $10^{\mathrm{T}}$ is reported to be a natural high surfactin producing strain yielding up to $1.1 \mathrm{~g} / \mathrm{L}$ surfactin in shake flask cultivation (Willenbacher et al. 2015b). In addition, for this strain, literature dealing with both the aerobic and anaerobic synthesis of surfactin was reported (Willenbacher et al. 2014, 2015a) giving a reliable comparison to results obtained within this study.

The current study aimed at evaluating the effects of genome reduction on the synthesis of surfactin in $B$. subtilis 168 with a functional $s f p$ gene. To get a more fundamental background, the cultivations were performed at different temperatures and under both aerobic and anaerobic conditions. The constructed genome reduced strain was evaluated with respect to biotechnological efficiency parameters including growth rates and yields and compared to the type-strain DSM $10^{\mathrm{T}}$ as well as the laboratory strain 168 carrying a functional $s f p$.

\section{Materials and methods} Chemicals and materials

All chemicals used were purchased from Carl Roth $\mathrm{GmbH} \&$ Co. KG (Karlsruhe, Germany) and were of analytical grade. The reference material for the lipopeptide surfactin $(\geq 98 \%)$ was obtained from Sigma-Aldrich Laborchemikalien GmbH (Seelze, Germany).

\section{DNA manipulation, plasmid construction and propagation}

Molecular techniques were carried out according to (Green and Sambrook 2012). The plasmids used or constructed in this study are listed in Additional file 1: Table S1 together with their construction procedure. To amplify the desired DNA fragments, polymerase chain reactions (PCRs) were performed using a polymerase (Q5 ${ }^{\circledR}$ High-Fidelity DNA Polymerase \#M0491S, New England BioLabs ${ }^{\circledR}$, Frankfurt am Main, Germany). The PCRs were run on a PCR thermal cycler (LifeECO BTC42096, Hangzhou Bioer Technology Co. Ltd., China). As a template for PCR, the chromosomal DNA (cDNA) of B. subtilis 168 was used unless otherwise specified. The cDNA of each strain was extracted with a DNA extraction kit (DNeasy ${ }^{\circledR}$ Blood \& Tissue Kit from Qiagen (Hilden, Germany) as instructed by the manufacturer. All oligonucleotides used for PCR were synthesized by Eurofins MWG Operons (Ebersberg, Germany) (Additional file 1: Table S2). DNA fragments were digested with restriction enzymes purchased from New England BioLabs ${ }^{\circledR}$ (Frankfurt am Main, Germany). To purify PCR products or DNA fragments cut from agarose gel were purified employing respective kits (NucleoSpin ${ }^{\circledR}$ Gel and PCR Clean-up, Macherey-Nagel $\mathrm{GmbH}$, Düren, Germany). The purified DNA fragments were ligated by T4 DNA ligase (Thermo Fisher Scientific, Karlsruhe, Germany). The constructed plasmid DNAs were finally extracted (innuPREP Plasmid Mini Kit, Analytik Jena AG, Jena, Germany) and sequenced 
(GATC Biotech AG, Konstanz, Germany). To propagate the desired plasmids, Escherichia coli JM109 (YanischPerron et al. 1985) was employed. The transformants of $E$. coli were selected on LB agar supplemented with $100 \mu \mathrm{g} / \mathrm{mL}$ ampicillin or spectinomycin according to the plasmid selection marker.

\section{Construction of the $B$. subtilis strains}

All final strains used in this study are given in Table 1 and their construction procedure are thoroughly described in Additional file 1: Table S3. The parental strains of $B$. subtilis, namely the wild-type surfactin producing strain DSM $10^{\mathrm{T}}$ and the laboratory model strain 168, were purchased from the DSMZ (German Collection of Microorganisms and Cell Cultures, Braunschweig, Germany). Transformation of B. subtilis strains were performed according to "Paris method" (Harwood and Cutting 1990) and the transformants were selected on LB with $100 \mu \mathrm{g} / \mathrm{mL}$ spectinomycin. As a parental strain for genome manipulation, the genome reduced strain IIG-Bs20-3, a derivative of strain 168 with tryptophan prototrophy and deletion of prophages and antibiotic biosynthesis genes, was used in this study (Wenzel and Altenbuchner 2015) To induce the competence in IIG-Bs20-3, a cassette containing comK and comS under control of the mannitol-inducible promoter $(m t l A)$ was inserted at the $3^{\prime}$-end of the histidine biosynthesis operon as reported by Rahmer et al. (2015) to generate strain IIG-Bs20-5. Markerless integration of the $\mathrm{P}_{m t l A}$-comKS cassette was performed based on a histidine auxotrophy system developed by Motejadded and Altenbuchner (2007). To enable the production of surfactin in the desired strains, the frameshift mutation in $s f p$ (shown as $s f p^{*}$ ) was removed by transformation of the cells with pJOE8949.1. Plasmid pJOE8949.1 was an integrative plasmid carrying the functional copy of $s f p$. The gene integration was performed based on selection with spectinomycin and anti-selection on LB medium with mannose according to the method of the mannose deletion system (Wenzel and Altenbuchner 2015).

\section{Cultivation conditions and preparation of culture samples Mineral salt medium and flask preparation}

The mineral salt medium investigated by Willenbacher et al. (2014) was used for aerobic cultivations. The final medium contained $1 \%$ glucose $(\mathrm{m} / \mathrm{v}), 4.0 \times 10^{-6}$ $\mathrm{M} \mathrm{Na} 2$ EDTA $\times 2 \mathrm{H}_{2} \mathrm{O}, 7.0 \times 10^{-6} \mathrm{M} \mathrm{CaCl}_{2}, 4.0 \times 10^{-6}$ $\mathrm{M} \mathrm{FeSO}_{4} \times 7 \mathrm{H}_{2} \mathrm{O}, 1.0 \times 10^{-6} \mathrm{M} \mathrm{MnSO}_{4} \times \mathrm{H}_{2} \mathrm{O}, 0.1 \mathrm{M}$ $\mathrm{NH}_{4} \mathrm{Cl}, 0.03 \mathrm{M} \mathrm{KH}_{2} \mathrm{PO}_{4}, 0.04 \mathrm{M} \mathrm{Na}_{2} \mathrm{HPO}_{4} \times 2 \mathrm{H}_{2} \mathrm{O}$ and $8.0 \times 10^{-4} \mathrm{M} \mathrm{MgSO}_{4} \times 7 \mathrm{H}_{2} \mathrm{O}$. For $1 \mathrm{~L}$ medium, $\mathrm{KH}_{2} \mathrm{PO}_{4}$, $\mathrm{Na}_{2} \mathrm{HPO}_{4} \times 2 \mathrm{H}_{2} \mathrm{O}$ and $\mathrm{NH}_{4} \mathrm{Cl}$ were diluted in a total volume of $969 \mathrm{~mL}$ demineralized $\mathrm{H}_{2} \mathrm{O}$ and this solution was autoclaved after adjusting the $\mathrm{pH}$ to 7 with $10 \mathrm{M} \mathrm{NaOH}$. The remaining components were added afterwards from individual stock solutions: $20 \mathrm{~mL}$ of an autoclaved $50 \%$ $(m / v)$ glucose solution, $1 \mathrm{~mL}$ of a filter-sterilized trace element solution containing $4 \times 10^{-3} \mathrm{M} \mathrm{Na}_{2}$ EDTA $\times 2$ $\mathrm{H}_{2} \mathrm{O}, 7.0 \times 10^{-3} \mathrm{M} \mathrm{CaCl}_{2}, 4 \times 10^{-3} \mathrm{M} \mathrm{FeSO}_{4} \times 7 \mathrm{H}_{2} \mathrm{O}$, $1 \times 10^{-3} \mathrm{M} \mathrm{MnSO}_{4} \times \mathrm{H}_{2} \mathrm{O}$, and $10 \mathrm{~mL}$ of a $\mathrm{MgSO}_{4}$ solution with $8 \times 10^{-2} \mathrm{M} \mathrm{MgSO}_{4} \times 7 \mathrm{H}_{2} \mathrm{O}$. Aerobic cultivations were performed in $1 \mathrm{~L}$ baffled shake flasks with $100 \mathrm{~mL}$ medium. For anaerobic cultivations, the nitrogen source was replaced by $0.025 \mathrm{M} \mathrm{NH}_{4} \mathrm{Cl}$ and $0.1 \mathrm{M}$ $\mathrm{NaNO}_{3} .96 .9 \mathrm{~mL}$ of this solution were filled in $100 \mathrm{~mL}$ serum flasks. The flasks were sealed using crimp seals with a septum. Prior to autoclaving, all serum flasks were equipped with a filter in order to allow air outflow. Afterwards, $2 \mathrm{~mL}$ of the $50 \%(\mathrm{~m} / \mathrm{v})$ glucose solution, $0.1 \mathrm{~mL}$ of the filter-sterilized trace element stock solution and $1 \mathrm{~mL}$ of the $\mathrm{MgSO}_{4}$ stock solution were added using a sterile syringe and canula. To remove residual oxygen in the serum flasks, sterile $\mathrm{N}_{2}$-gas was purged through the medium for 5 min via filters.

Table 1 Overview of strains used in the current study

\begin{tabular}{|c|c|}
\hline Strain & Genotype or description \\
\hline \multicolumn{2}{|l|}{ B. subtilis } \\
\hline DSM10 ${ }^{\top}$ & Wild-type strain ${ }^{\mathrm{a}}$ \\
\hline JABs24 & $\begin{array}{l}\operatorname{trp}^{+} s f p^{+} \triangle m a n P A \text {, (Morabbi Heravi and Altenbuchner 2018) and (Reuß et al. } \\
\text { 2017), see electronic supplementary material for detailed strain history }\end{array}$ \\
\hline IIG-Bs-20-5-1 & 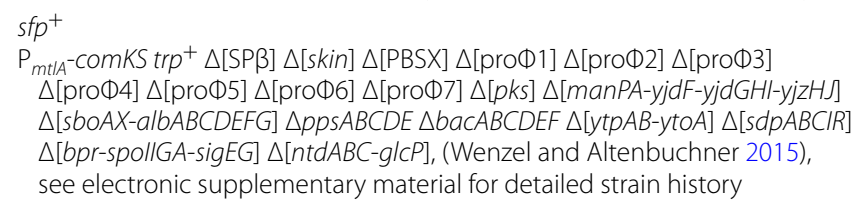 \\
\hline
\end{tabular}

\footnotetext{
a Deutsche Sammlung von Mikroorganismen und Zellkulturen GmbH (German collection of microorganisms and cell cultures)
} 


\section{Preparation of inoculum cultures}

The first pre-culture was prepared by inoculating $20 \mathrm{~mL}$ LB medium (5 g/L tryptone, $10 \mathrm{~g} / \mathrm{L} \mathrm{NaCl}, 10 \mathrm{~g} / \mathrm{L}$ yeast extract) with $100 \mu \mathrm{L}$ of the respective glycerol stock in a $100 \mathrm{~mL}$ baffled shake flask. The shake flasks were incubated at $120 \mathrm{rpm}$ and $30{ }^{\circ} \mathrm{C}$ for $24 \mathrm{~h}$ in an incubator shaker (Newbrunswick ${ }^{\mathrm{TM}} /$ Innova $^{\circledR}$ 44, Eppendorf AG, Hamburg, Germany). The second pre-culture was prepared in $250 \mathrm{~mL}$ baffled shake flasks by diluting the respective LB-pre-culture each 1:10 and 1:20 in a final volume of $50 \mathrm{~mL}$ aerobic mineral salt medium. These pre-cultures were incubated for another $12 \mathrm{~h}$ and $24 \mathrm{~h}$ for the $1: 10$ and 1:20-dilutions, respectively.

\section{Main culture}

All aerobic and anaerobic cultivations were performed at 25, 30, 37 and $40{ }^{\circ} \mathrm{C}$ and $120 \mathrm{rpm}$ in an incubator shaker (Newbrunswick ${ }^{\mathrm{TM}} /$ Innova $^{\circledR} 44$, Eppendorf AG, Hamburg, Germany). Serum flasks were incubated in a horizontal manner. For each temperature, four shake flasks and four serum flasks were prepared. Each two flasks were inoculated with a time difference of $12 \mathrm{~h}$ using the 1:10-dilution pre-cultures for the first set of duplicates, and the 1:20-dilution pre-cultures for the second set of duplicates. All shake flasks and serum flasks were inoculated with a resulting $\mathrm{OD}_{600}$ of 0.1 .

\section{Sampling and sample analysis}

Samples were taken regularly from the individual four flasks to cover every other hour of the growth phase and samples were analyzed regarding the $\mathrm{OD}_{600}$, glucose and surfactin concentrations. The $\mathrm{OD}_{600}$ was determined using a spectrophotometer (Biochrom WPA CO8000, Biochrom Ltd., Cambridge, UK). Prior to further analysis, cells were removed by centrifuging for $10 \mathrm{~min}$ at $4700 \mathrm{rpm}$ at $4{ }^{\circ} \mathrm{C}$ (Heraeus X3R, Thermo Fisher Scientific $\mathrm{GmbH}$, Braunschweig, Germany).

Surfactin was analyzed using a HPTLC system (CAMAG, Muttenz, Switzerland) with a validated method as described previously (Geissler et al. 2017). In brief, a threefold extraction of $2 \mathrm{~mL}$ cell-free broth with each $2 \mathrm{~mL}$ chloroform/methanol 2:1 ( $v / v)$ was conducted. The pooled solvent layers obtained after each extraction were evaporated to dryness in a rotary evaporator (RVC2-25 Cdplus, Martin Christ Gefriertrocknungsanlagen $\mathrm{GmbH}$, Osterode am Harz, Germany) at 10 mbar and $40{ }^{\circ} \mathrm{C}$. For HPTLC analysis, samples were resuspended in $2 \mathrm{~mL}$ methanol and applied as $6 \mathrm{~mm}$ bands on HPTLC silica gel 60 plates from Merck (Darmstadt, Germany). A surfactin standard curve was applied in the range of 30-600 ng/band. The development was conducted using chloroform/methanol/water $(65: 25: 4, v / v / v)$ over a migration distance of $60 \mathrm{~mm}$. After the development, the plate was scanned at $195 \mathrm{~nm}$ to quantify surfactin.

Glucose concentrations were determined using a HPTLC method as well. Proper diluted cell-free supernatants were applied as $6 \mathrm{~mm}$ bands and the plate was developed with acetonitrile $/ \mathrm{H}_{2} \mathrm{O}(85: 15, v / v)$ over a migration distance of $70 \mathrm{~mm}$. After development, the plate was dipped in the derivatization solution diphenylamine (DPA) for $3 \mathrm{~s}$ and the plate was heated for $20 \mathrm{~min}$ at $120{ }^{\circ} \mathrm{C}$ using the TLC plate heater. DPA reagent was prepared by first dissolving $2.4 \mathrm{~g}$ diphenylamine and $2.4 \mathrm{~g}$ aniline in $200 \mathrm{~mL}$ methanol and then adding $20 \mathrm{~mL} 85 \%$ phosphoric acid.

For further data analysis, the OD/cell dry weight (CDW) conversion factor was determined in a pre-liminary test. Therefore, the strains were cultivated as triplicates as described above for aerobic conditions until reaching the range of maximum $\mathrm{OD}_{600} .40 \mathrm{~mL}$ culture were filled in dried and pre-weighted falcons and centrifuged for $10 \mathrm{~min}$ at $4700 \mathrm{rpm}$ and $4{ }^{\circ} \mathrm{C}$. The supernatant was discarded, and the cell pellet was washed with saline solution prior to a second round of centrifugation. After discarding the supernatant, the weight of the cell pellets were determined after drying the loaded falcons at $110{ }^{\circ} \mathrm{C}$ for $24 \mathrm{~h}$ and the conversion factor was calculated. In this sense, the OD/CDW conversion factor for all strains used was determined as $3.76 \pm 0.17$ with a $\% R S D$ of $4.47 \%$.

\section{Data analysis}

Biomass concentrations $(\mathrm{g} / \mathrm{L})$, glucose concentrations $(\mathrm{g} / \mathrm{L})$ and surfactin concentrations $(\mathrm{g} / \mathrm{L})$ for aerobic and anaerobic cultivations during the time course of cultivation were plotted for the individual strains and temperatures. Several process parameter were calculated for all cultivations conducted. Here, the mean values obtained for two time points were used, labelled $m_{1}$ and $m_{2}$. The first time point used for calculation was at $0 \mathrm{~h}$ of cultivation with all corresponding data. The second time point corresponded to $\mathrm{CDW}_{\max }$. Again, all data measured at this time point were used for calculation. In addition, calculations were based on absolute values, as this compensated for the different amounts of samples taken, especially for the long lasting anaerobic cultivations. Using absolute values furthermore allowed for better comparison with literature and future planned bioreactor cultivations.

The biomass yield on substrate $Y_{\mathrm{X} / \mathrm{S}}(\mathrm{g} / \mathrm{g})$, product yield on substrate $Y_{\mathrm{P} / \mathrm{S}}(\mathrm{g} / \mathrm{g})$ and the product yield on biomass $Y_{\mathrm{P} / \mathrm{X}}(\mathrm{g} / \mathrm{g})$ were calculated using Eqs. 1, 2 and 3, respectively.

$$
\begin{aligned}
Y_{\mathrm{X} / \mathrm{S}} & =\frac{\Delta m_{\mathrm{CDW}}}{\Delta m_{\text {glucose }}} \\
Y_{\mathrm{P} / \mathrm{X}} & =\frac{\Delta m_{\text {surfactin }}}{\left(\frac{\left(m_{\mathrm{CDW}_{1}}+m_{\mathrm{CDW}_{2}}\right)}{2}\right)}
\end{aligned}
$$




$$
Y_{\mathrm{P} / \mathrm{S}}=\frac{\Delta m_{\text {surfactin }}}{\Delta m_{\text {glucose }}}
$$

The growth rate was calculated using Eq. 4.

$$
\mu=\frac{\ln \frac{m_{\mathrm{CDW}_{2}}}{m_{\mathrm{CDW}}}}{t_{2}-t_{1}}
$$

The specific productivity $q_{\text {spec,surfactin }}\left(\mathrm{g}_{\text {surfactin }} / \mathrm{g}_{\mathrm{CDW}} \mathrm{h}\right)$ was calculated using Eq. 5.

$$
q_{\text {spec.surfactin }}=\frac{\Delta m_{\text {surfactin }}}{\left(\frac{\left(m_{\mathrm{CDW}_{1}}+m_{\mathrm{CDW}_{2}}\right)}{2}\right) \cdot \Delta t}
$$

In order to evaluate the reliability of the obtained data, an overall maximum relative standard deviation $\left(\mathrm{RSD}_{\max }\right)$ was determined for CDW, surfactin concentration and glucose concentration individually. Therefore, the relative standard deviations of the flasks at $t_{C D W \max }$ were used and the mean value of the corresponding duplicates at $\mathrm{t}_{0 \mathrm{~h}}$. Both the mean RSD (RSD mean $)$ as well as the corresponding standard deviation $\left(\mathrm{SD}_{\mathrm{RSD} \text { mean }}\right)$ were determined for these individual RSD. The $\mathrm{RSD}_{\max }$ was then calculated as $\mathrm{RSD}_{\text {mean }}+\mathrm{SD}_{\mathrm{RSD} \text { mean }}$, and was determined as $12.23 \%, 8.53 \%$ and $0.10 \%$ for CDW, surfactin concentration and glucose concentration, respectively.

\section{Results}

We hypothesized that the genome reduced strain $B$. subtilis IIG-Bs20-5-1 shows a similar growth behavior as compared to the reference strain B. subtilis JABs24 and yields higher surfactin concentrations. To get a more fundamental background on the effects of genome reduction, the cultivations were performed at four different temperatures and under both aerobic and anaerobic conditions. In addition, the high surfactin producing strain B. subtilis DSM $10^{\mathrm{T}}$ was used as further reference strain to evaluate the overall performance of the two main strains deriving from the non-surfactin producer $B$. subtilis 168.

\section{Aerobic cultivations are superior to anaerobic cultivations with respect to $\mathrm{CDW}_{\text {max }}$ and surfactin concentration}

Figure 1 displays the CDW, glucose consumption and surfactin concentration during the time course of aerobic (A) and anaerobic (B) cultivation employing the strain B. subtilis JABs 24 at $37{ }^{\circ} \mathrm{C}$. The exemplary graphs depict the main differences for aerobic and anaerobic conditions, which are valid for all strains at all temperatures tested. The main data, including $\mathrm{CDW}_{\text {max }}$, surfactin $_{\mathrm{CDW}}$ max.' glucose $\mathrm{CDW}_{\mathrm{CDax}}, \mathrm{t}_{\mathrm{CDW} \text { max.' }}$ as well as the overall

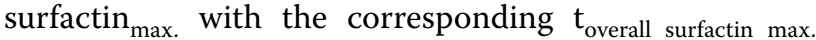
are further summarized in Table 2 (aerobic) and Table 3 (anaerobic). Briefly, aerobic cultivations yielded 4.6- to 10-fold higher CDW, reached two to tenfold higher surfactin concentrations and the time of complete glucose consumption and concomitant the time to reach $\mathrm{CDW}_{\max }$ were much shorter by factors 2 to 6 for all cultivations employed.

Under aerobic conditions, except for strain JABs24 at $25^{\circ} \mathrm{C}$, where a glucose concentration of $0.81 \mathrm{~g} / \mathrm{L}$ was measured, glucose was completely consumed under aerobic conditions when $\mathrm{CDW}_{\max }$ was reached. For all strains, the highest $\mathrm{CDW}$ was reached at $37{ }^{\circ} \mathrm{C}$ with $1.95 \mathrm{~g} / \mathrm{L}, 2.17 \mathrm{~g} / \mathrm{L}$ and $2.10 \mathrm{~g} / \mathrm{L}$ for strains JABs24, IIGBs20-5-1 and DSM $10^{\mathrm{T}}$, respectively. For both IIGBs20-5-1 and DSM $10^{\mathrm{T}}$, the lowest CDW was obtained at $25{ }^{\circ} \mathrm{C}$ with $1.54 \mathrm{~g} / \mathrm{L}$ and $1.58 \mathrm{~g} / \mathrm{L}$, respectively. JABs24 yielded the lowest CDW at $30^{\circ} \mathrm{C}$ with $1.27 \mathrm{~g} / \mathrm{L}$. Considering the mean $\mathrm{CDW}_{\max }$ of the three strains at the temperatures tested, the overall \%RSD of the $\mathrm{CDW}_{\max }$ obtained was $15.94 \%, 12.77 \%$ and $10.71 \%$ for strains JABs24, IIGBs20-5-1 and DSM $10^{\mathrm{T}}$, respectively. The time to reach the highest $\mathrm{CDW}$ was shorter the higher the temperature was. In comparison, at $25{ }^{\circ} \mathrm{C}$ the cultivation time of $\mathrm{CDW}_{\max }$ varied between 54 and $72 \mathrm{~h}$, whereas at $40{ }^{\circ} \mathrm{C}$ glucose consumption was obtained after 15 to $18 \mathrm{~h}$ of cultivation. Amongst the three strains tested, strain JABs24 yielded the highest surfactin concentration at $37{ }^{\circ} \mathrm{C}$ with $1147.03 \mathrm{mg} / \mathrm{L}$. For strain IIG-Bs20-5-1, the highest concentration was also detected at $37{ }^{\circ} \mathrm{C}$ with $993.03 \mathrm{mg} / \mathrm{L}$. Strain DSM $10^{\mathrm{T}}$, however, synthesized the highest concentration of $446.12 \mathrm{mg} / \mathrm{L}$ at $25{ }^{\circ} \mathrm{C}$, followed by $37^{\circ} \mathrm{C}$ with $353.93 \mathrm{mg} / \mathrm{L}$. During the stationary phase, surfactin concentrations further increased by a factor of 1.09 to 2.24. In general, lowest increase was monitored for strain IIG-Bs20-5-1, followed by strain JABs24 and highest increase was obtained for strain DSM $10^{\mathrm{T}}$. The final overall highest concentration for the latter strain was monitored at $37{ }^{\circ} \mathrm{C}$ with an increase from 353.93 to $793 \mathrm{mg} / \mathrm{L}$, which is lower than the highest concentrations obtained for strains JABs24 and IIG-Bs20-5-1.

As shown in Table 3, summarizing the data for anaerobic cultivations, glucose in general was not completely consumed under anaerobic conditions when $\mathrm{CDW}_{\max }$ was reached. A trend regarding glucose consumption was not observed amongst the strains and temperatures tested. For example, for strain IIG-Bs20-5-1 with increasing temperature, $4.63 \mathrm{~g} / \mathrm{L}, 0.00 \mathrm{~g} / \mathrm{L}, 0.00 \mathrm{~g} / \mathrm{L}$ and $3.25 \mathrm{~g} / \mathrm{L}$ were measured prior to an observed decline in CDW. Similar to aerobic cultivations, the time to reach $\mathrm{CDW}_{\max }$ was shorter the higher the temperature was set. Excluding strain DSM $10^{\mathrm{T}}$, the time varied between 144 and $176 \mathrm{~h}$ at $25^{\circ} \mathrm{C}$, and 24 to $42 \mathrm{~h}$ at $40{ }^{\circ} \mathrm{C}$. Strain DSM $10^{\mathrm{T}}$, however, reached 


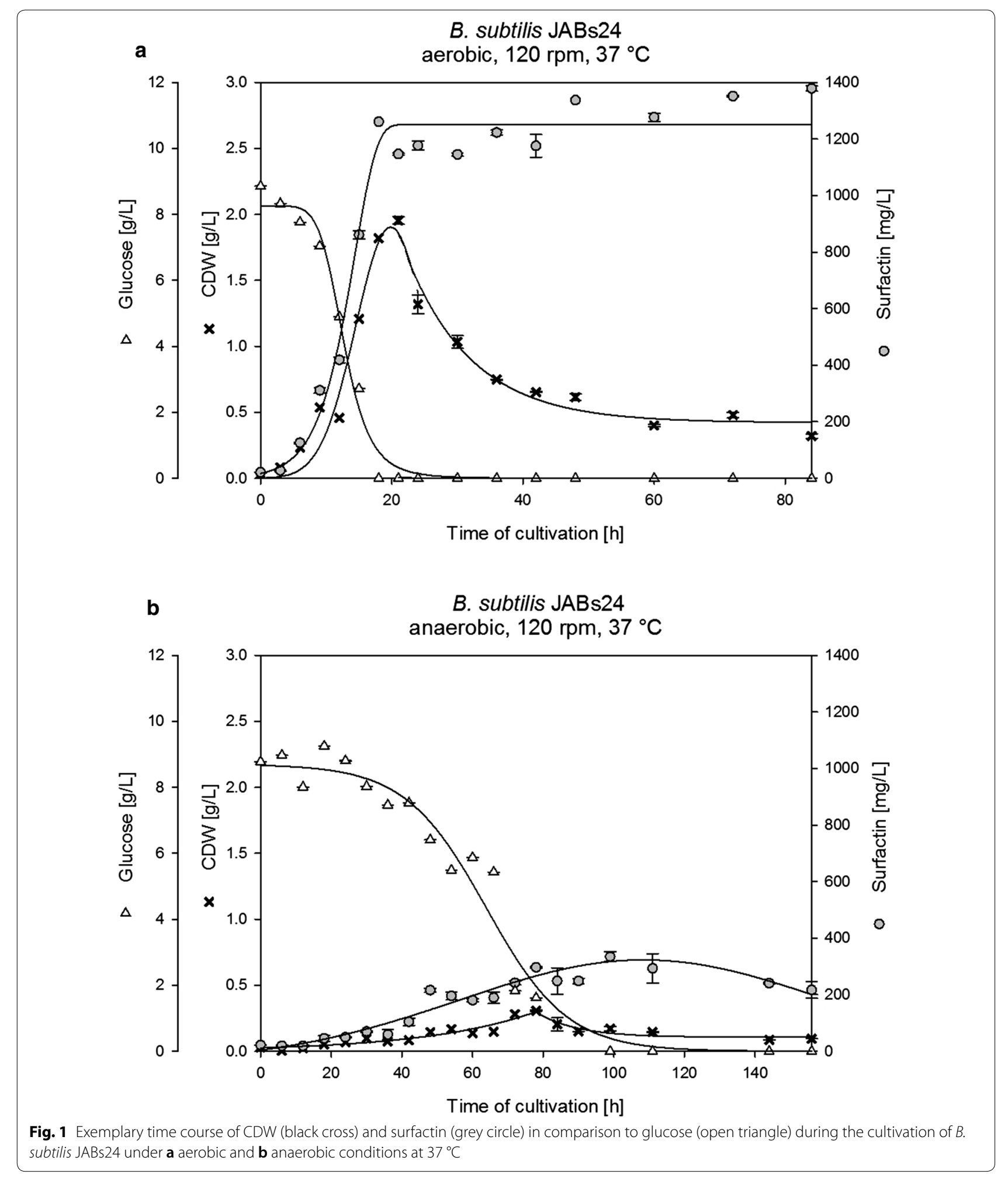

the $\mathrm{CDW}_{\max }$ after $90 \mathrm{~h}$ of cultivation at $30{ }^{\circ} \mathrm{C}, 37^{\circ} \mathrm{C}$ and $40{ }^{\circ} \mathrm{C}$. With respect to $\mathrm{CDW}_{\max }$, all strains reached the lowest value at $25{ }^{\circ} \mathrm{C}$. Amongst the other temperatures tested, no trend was observed, and data varied between 0.26 and $0.45 \mathrm{~g} / \mathrm{L}$. With respect to surfactin, anaerobic cultivations showed a similar pattern as compared to aerobic 
Table 2 Summary of the results obtained for aerobic cultivations at various temperatures

\begin{tabular}{|c|c|c|c|c|c|c|c|}
\hline \multicolumn{8}{|c|}{ Aerobic shake flask cultivation } \\
\hline $\mathrm{T}\left({ }^{\circ} \mathrm{C}\right)$ & B. subtilis strain & $\mathrm{CDW}_{\max }(\mathrm{g} / \mathrm{L})$ & $\begin{array}{l}\text { Surfactin } \\
\text { (mg/L) }\end{array}$ & $\begin{array}{l}\text { Glucose }{ }_{\text {CDW max }} \\
(g / L)\end{array}$ & $t_{C D W \text { max }}(h)$ & $\begin{array}{l}\text { Overall } \\
\text { surfactin }_{\text {max }} \\
\text { (mg/L) }\end{array}$ & $\begin{array}{l}t_{\text {overall }} \\
\text { surfactin max } \\
\text { (h) }\end{array}$ \\
\hline \multirow[t]{3}{*}{25} & JABs24 & 1.63 & 766.15 & 0.81 & 54 & 1189.15 & 156 \\
\hline & IIG-Bs20-5-1 & 1.54 & 654.29 & 0.00 & 72 & 970.80 & 156 \\
\hline & DSM $10^{\top}$ & 1.58 & 446.12 & 0.00 & 60 & 740.32 & 84 \\
\hline \multirow[t]{3}{*}{30} & JABs24 & 1.27 & 602.98 & 0.00 & 36 & 836.23 & 42 \\
\hline & $\| G-B s 20-5-1$ & 2.12 & 676.46 & 0.00 & 36 & 740.34 & 144 \\
\hline & DSM $10^{\top}$ & 1.84 & 209.06 & 0.00 & 30 & 415.79 & 156 \\
\hline \multirow[t]{3}{*}{37} & JABs24 & 1.95 & 1147.03 & 0.00 & 21 & 1378.50 & 84 \\
\hline & IIG-Bs20-5-1 & 2.17 & 993.03 & 0.00 & 18 & 1083.92 & 48 \\
\hline & DSM $10^{\top}$ & 2.10 & 353.93 & 0.00 & 18 & 793.61 & 60 \\
\hline \multirow[t]{3}{*}{40} & JABs24 & 1.88 & 670.58 & 0.00 & 18 & 1079.58 & 24 \\
\hline & IIG-Bs20-5-1 & 2.09 & 681.63 & 0.00 & 18 & 766.72 & 72 \\
\hline & DSM $10^{\top}$ & 2.04 & 203.45 & 0.00 & 15 & 406.16 & 84 \\
\hline
\end{tabular}

Table 3 Summary of the results obtained for anaerobic cultivations at various temperatures

\begin{tabular}{|c|c|c|c|c|c|c|c|}
\hline \multicolumn{8}{|c|}{ Anaerobic serum flask cultivation } \\
\hline $\mathrm{T}\left({ }^{\circ} \mathrm{C}\right)$ & B. subtilis strain & $\mathrm{CDW}_{\max }(\mathrm{g} / \mathrm{L})$ & $\begin{array}{l}\text { Surfactin }_{\mathrm{CDW} \max } \\
(\mathrm{mg} / \mathrm{L})\end{array}$ & $\begin{array}{l}\text { Glucose }_{\text {CDW max }} \\
\text { (g/L) }\end{array}$ & $t_{\text {CDW max }}(h)$ & $\begin{array}{l}\text { Overall } \\
\text { surfactin }_{\max } \\
(\mathrm{mg} / \mathrm{L})\end{array}$ & $\begin{array}{l}t_{\text {overall }} \\
\text { surfactin max } \\
\text { (h) }\end{array}$ \\
\hline \multirow[t]{3}{*}{25} & JABs24 & 0.26 & 87.67 & 0.41 & 176 & 87.67 & 176 \\
\hline & $\| G-B s 20-5-1$ & 0.19 & 79.46 & 4.63 & 144 & 79.46 & 144 \\
\hline & DSM $10^{\top}$ & 0.16 & 96.90 & 5.70 & 156 & 96.90 & 156 \\
\hline \multirow[t]{3}{*}{30} & $J A B s 24$ & 0.26 & 209.53 & 5.03 & 90 & 209.53 & 90 \\
\hline & IIG-Bs20-5-1 & 0.41 & 189.64 & 0.00 & 90 & 189.64 & 90 \\
\hline & DSM $10^{\top}$ & 0.33 & 76.14 & 6.17 & 90 & 146.64 & 144 \\
\hline \multirow[t]{3}{*}{37} & $\mathrm{JABs} 24$ & 0.31 & 296.37 & 1.62 & 78 & 333.92 & 99 \\
\hline & ॥G-Bs20-5-1 & 0.39 & 215.31 & 0.00 & 60 & 273.38 & 111 \\
\hline & DSM 10T & 0.45 & 180.65 & 0.00 & 90 & 181.86 & 111 \\
\hline \multirow[t]{3}{*}{40} & $\mathrm{JABs} 24$ & 0.39 & 75.80 & 2.35 & 42 & 211.24 & 90 \\
\hline & IIG-Bs20-5-1 & 0.26 & 75.96 & 3.25 & 24 & 158.34 & 90 \\
\hline & DSM $10^{\top}$ & 0.39 & 110.03 & 1.71 & 90 & 111.56 & 84 \\
\hline
\end{tabular}

cultivations. At $37{ }^{\circ} \mathrm{C}$, all strains synthesized the highest amounts of surfactin with $296.37 \mathrm{~g} / \mathrm{L}, 215.31 \mathrm{~g} / \mathrm{L}$ and $180.65 \mathrm{~g} / \mathrm{L}$ at $\mathrm{CDW}_{\max }$. At $25^{\circ} \mathrm{C}$, the overall surfactin ${ }_{\max }$ matched the concentration at $\mathrm{CDW}_{\max }$. A similar result was obtained for strains JABs24 and IIG-Bs20-5-1 at $30{ }^{\circ} \mathrm{C}$. The highest increase of surfactin was detected for strain DSM $10^{\mathrm{T}}$ at $30^{\circ} \mathrm{C}$, as well as for strains JABs24 and IIGBs20-5-1 at $40{ }^{\circ} \mathrm{C}$ where the concentration reached values of 1.93- to 2.79-fold higher. Considering the overall highest surfactin concentration, strain DSM $10^{\mathrm{T}}$ was, similar to aerobic cultivations, inferior to strain JABs24 yielding the highest values.
Strain IIG-Bs20-5-1 yields higher growth rates $\mu$ and $Y_{\mathrm{X} / \mathrm{S}}$ than strain JABs24

As illustrated in Fig. 2, the growth rates $\mu(1 / \mathrm{h})$ increased with increasing temperature for all strains tested under both aerobic and anaerobic conditions. In accordance to the higher $C D W_{\max }$ reached and the reduced time to reach $\mathrm{CDW}_{\text {max }}$, aerobic cultivations possessed higher growth rates. For example, at $25{ }^{\circ} \mathrm{C}$ and $40{ }^{\circ} \mathrm{C}$, strain JABs 24 reached a growth rate of $0.0701 / \mathrm{h}$ and $0.2361 / \mathrm{h}$ under aerobic, and of $0.0121 / \mathrm{h}$ and $0.061 \mathrm{1} / \mathrm{h}$ under anaerobic conditions. Strain DSM $10^{\mathrm{T}}$ yielded higher growth rates under aerobic conditions than the other two strains except at $25{ }^{\circ} \mathrm{C}$. The genome reduced strain 


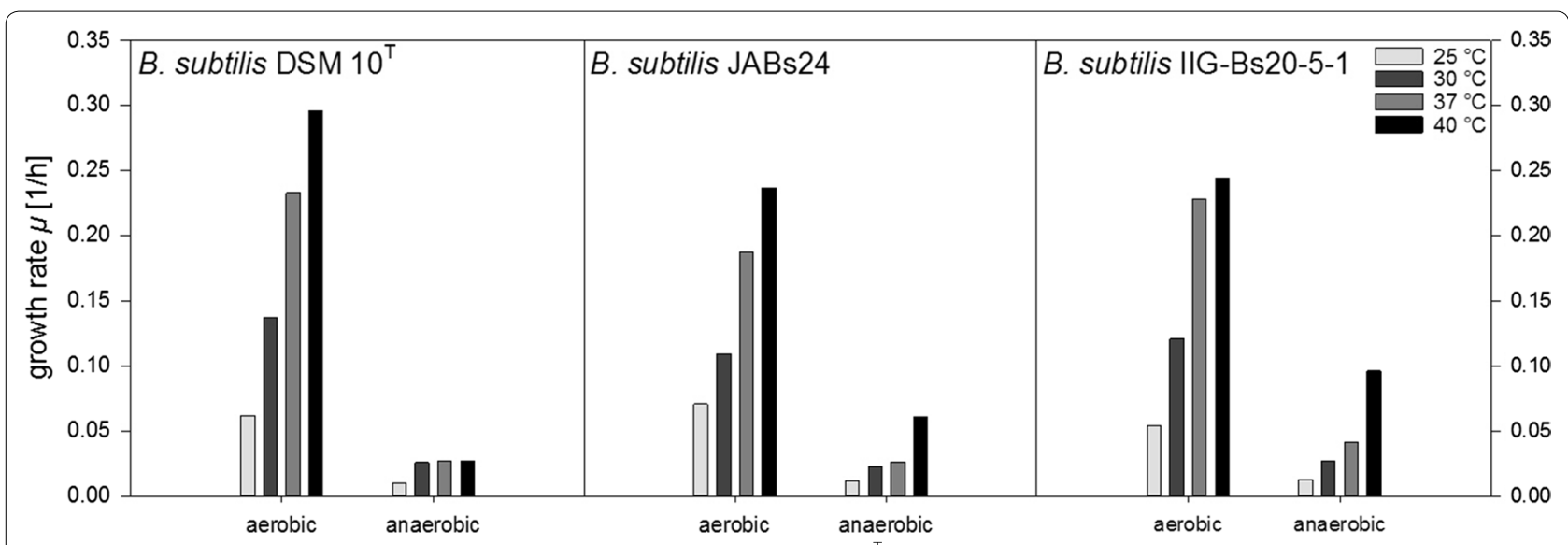

Fig. 2 Overview of the calculated growth rates $\mu(1 / \mathrm{h})$ for strains B. subtilis DSM $10^{\top}$, B. subtilis JABs 24 and B. subtilis IIG-Bs20-5-1 under aerobic and anaerobic conditions at $25^{\circ} \mathrm{C}, 30^{\circ} \mathrm{C}, 37^{\circ} \mathrm{C}$ and $40^{\circ} \mathrm{C}$

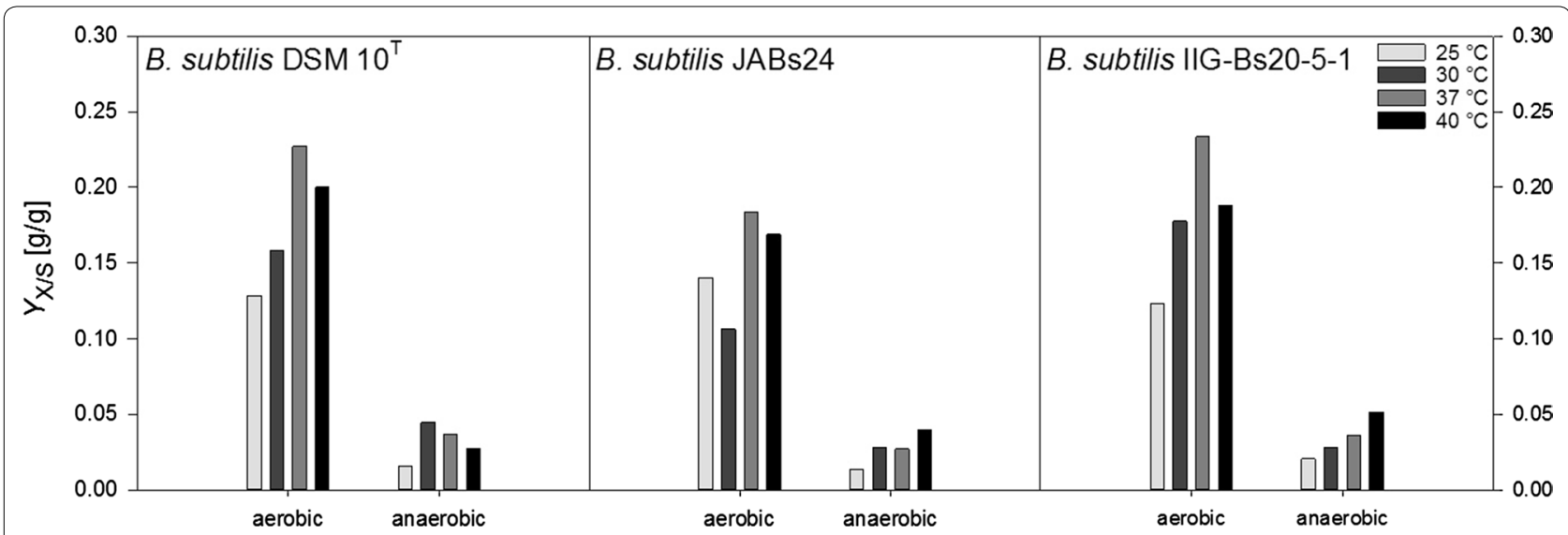

Fig. 3 Overview of the calculated biomass yields on substrate $Y_{X / S}(\mathrm{~g} / \mathrm{g})$ for strains B. subtilis DSM $10^{\top}$, B. subtilis JABs24 and B. subtilis $\| \mathrm{G}-\mathrm{Bs} 20-5-1$ under aerobic and anaerobic conditions at $25^{\circ} \mathrm{C}, 30^{\circ} \mathrm{C}, 37^{\circ} \mathrm{C}$ and $40^{\circ} \mathrm{C}$

furthermore performed better than strain JABs24, albeit the exception of $25{ }^{\circ} \mathrm{C}$. At this condition, JABs24 was superior to both other strains. Under anaerobic conditions, strain IIG-Bs20-5-1 surpassed the growth rates for JABs24 and DSM $10^{\mathrm{T}}$ at all temperatures tested, with the highest growth rate obtained at $40{ }^{\circ} \mathrm{C}$ with $0.0961 / \mathrm{h}$ and the lowest at $25^{\circ} \mathrm{C}$ with $0.0131 / \mathrm{h}$.

Figure 3 depicts the results obtained for the biomass yield on substrate $Y_{\mathrm{X} / \mathrm{S}}(\mathrm{g} / \mathrm{g})$. Under aerobic conditions, the highest conversion from glucose into biomass was obtained at $37^{\circ} \mathrm{C}$ with yields of $0.184 \mathrm{~g} / \mathrm{g}, 0.234 \mathrm{~g} / \mathrm{g}$ and $0.227 \mathrm{~g} / \mathrm{g}$ for strains JABs24, IIG-Bs20-5-1 and DSM $10^{\mathrm{T}}$, respectively. Except for strain JABs 24 at $25{ }^{\circ} \mathrm{C}$, values increased with increasing temperature and after reaching a maximum at $37{ }^{\circ} \mathrm{C}$, yields declined at $40{ }^{\circ} \mathrm{C}$. Though, values at $40{ }^{\circ} \mathrm{C}$ were still higher than at $30{ }^{\circ} \mathrm{C}$. Under anaerobic conditions, $Y_{\mathrm{X} / \mathrm{S}}$-values were much lower and did not surpass $0.051 \mathrm{~g} / \mathrm{g}$, which was obtained for strain
IIG-Bs20-5-1 at $40{ }^{\circ} \mathrm{C}$. In comparison to the data determined for the aerobic cultivations, a similar trend or strain possessing generally the highest conversion at the temperatures tested cannot be emphasized.

\section{Strain JABs24 yields outstanding values for $Y_{\mathrm{P} / \mathrm{X}}$ with the genome reduced strain being slightly inferior}

Figure 4 displays the product yield per substrate $Y_{\mathrm{P} / \mathrm{S}}(\mathrm{g} / \mathrm{g})$ for the different temperatures tested. $37{ }^{\circ} \mathrm{C}$ was superior under both aerobic and anaerobic conditions. Similar to the growth rate $\mu$ and the $Y_{\mathrm{X} / \mathrm{S}}$, aerobic calculated $Y_{\mathrm{P} / \mathrm{S}}$ were much higher than anaerobic values. The highest $Y_{\mathrm{P} / \mathrm{S}}$ were obtained under aerobic conditions at $37^{\circ} \mathrm{C}$ for strain JABs24 with $0.108 \mathrm{~g} / \mathrm{g}$ and for strain IIG-Bs20-5-1 with $0.105 \mathrm{~g} / \mathrm{g}$. These values were about twofold higher than at the other temperatures tested. Under anaerobic cultivations, the $Y_{\mathrm{P} / \mathrm{s}}$ at $37^{\circ} \mathrm{C}$ reached $0.027 \mathrm{~g} / \mathrm{g}$ and $0.018 \mathrm{~g} / \mathrm{g}$, respectively for these two strains. The variation of the 


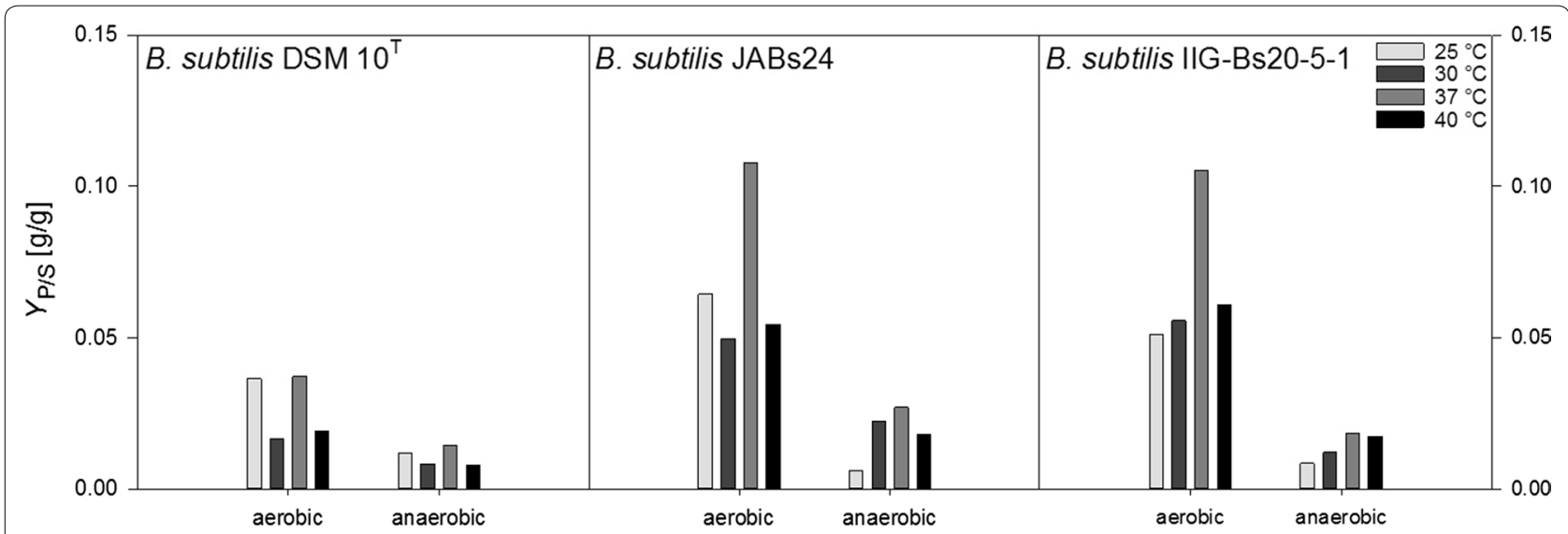

Fig. 4 Overview of the calculated product yields on substrate $Y_{P / S}(\mathrm{~g} / \mathrm{g})$ for strains B. subtilis DSM 10 ${ }^{\top}$, B. subtilis JABs24 and B. subtilis IIG-Bs20-5-1 under aerobic and anaerobic conditions at $25^{\circ} \mathrm{C}, 30^{\circ} \mathrm{C}, 37^{\circ} \mathrm{C}$ and $40^{\circ} \mathrm{C}$

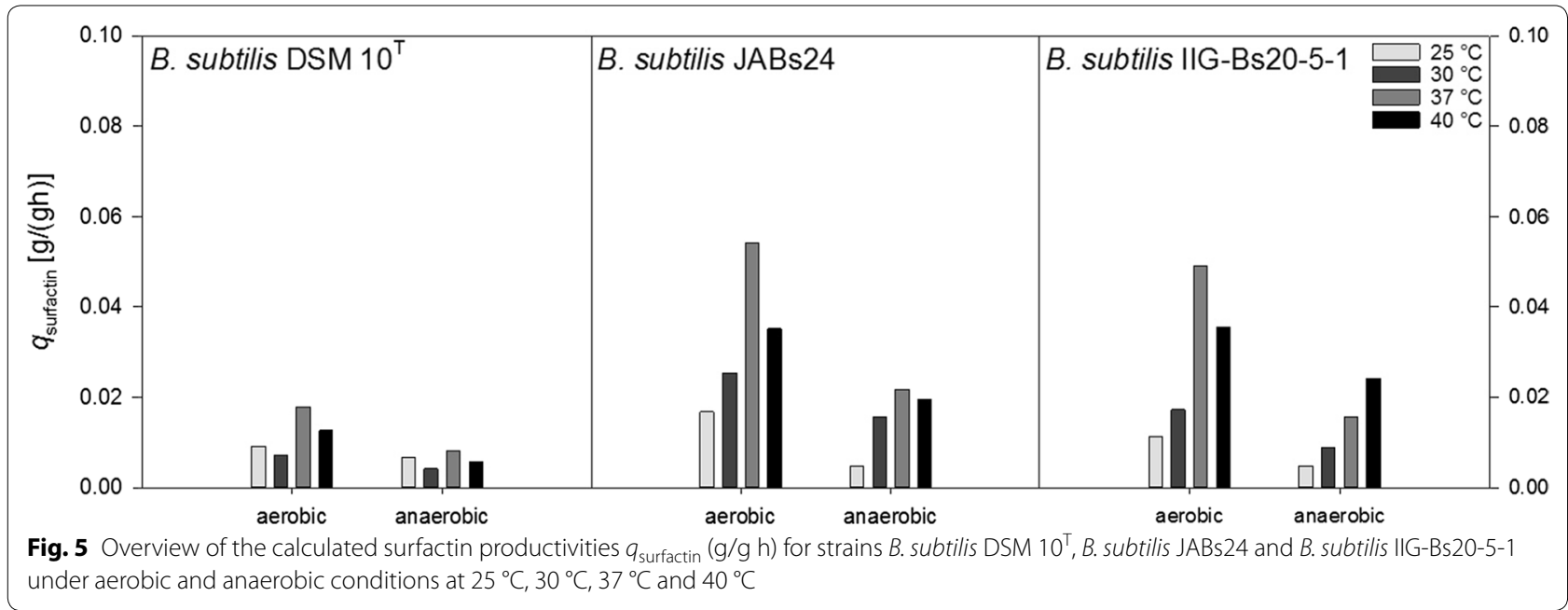

$Y_{\mathrm{P} / \mathrm{S}}$ was overall lower than under aerobic conditions. The $Y_{\mathrm{P} / \mathrm{S}}$ for strain DSM $10^{\mathrm{T}}$ did not surpass $0.037 \mathrm{~g} / \mathrm{g}$ under aerobic, and $0.015 \mathrm{~g} / \mathrm{g}$ under anaerobic conditions, both obtained at $37^{\circ} \mathrm{C}$, which correlates to the overall lower obtained surfactin concentrations.

Figure 5 illustrates the specific productivity $q_{\text {surfac- }}$ tin $(\mathrm{g} / \mathrm{g} \mathrm{h})$. With respect to the long cultivation times under anaerobic conditions, the values calculated were rather low. Here, a trend could be observed for strain IIG-Bs20-5-1, and the overall productivity increased from 0.005 to $0.024 \mathrm{~g} / \mathrm{g}$ h with increasing temperature. For strain JABs24, highest productivity was obtained at $37^{\circ} \mathrm{C}$ with $0.022 \mathrm{~g} / \mathrm{g}$ h. Strain DSM $10^{\mathrm{T}}$ showed the overall lowest productivity and values did not exceed $0.008 \mathrm{~g} / \mathrm{g}$ h. Under aerobic conditions, $37{ }^{\circ} \mathrm{C}$ was superior for all strains tested and productivities of $0.054 \mathrm{~g} / \mathrm{g} \mathrm{h}$, $0.049 \mathrm{~g} / \mathrm{g} \mathrm{h}$ and $0.018 \mathrm{~g} / \mathrm{g} \mathrm{h}$ were recorded for strains JABs24, IIG-Bs20-5-1 and DSM $10^{\mathrm{T}}$, respectively. $40{ }^{\circ} \mathrm{C}$ was furthermore superior to $30{ }^{\circ} \mathrm{C}$, similar to the observations for the $Y_{\mathrm{X} / \mathrm{s}}$.

Figure 6 shows the product yields per biomass $Y_{\mathrm{P} / \mathrm{X}}$ $(\mathrm{g} / \mathrm{g})$. The $Y_{\mathrm{P} / \mathrm{X}}$ for strain DSM $10^{\mathrm{T}}$ obtained at $25^{\circ} \mathrm{C}$ surpassed the values at the other three temperatures tested and reached $0.541 \mathrm{~g} / \mathrm{g}$ and $0.942 \mathrm{~g} / \mathrm{g}$ under aerobic and anaerobic conditions, respectively. $30^{\circ} \mathrm{C}$ yielded the lowest values, and $37^{\circ} \mathrm{C}$ was furthermore superior to $40{ }^{\circ} \mathrm{C}$. For strain DSM $10^{\mathrm{T}}$ the $Y_{\mathrm{P} / \mathrm{X}}$ was 1.48 - to 2.58 -fold higher under anaerobic conditions at all temperatures run. For strain JABs24, yields obtained anaerobically were 1.02- to 1.32 -fold higher at $30^{\circ} \mathrm{C}$ to $40{ }^{\circ} \mathrm{C}$, but 0.73 -fold lower at $25^{\circ} \mathrm{C}$. The highest yield was determined anaerobically at $37{ }^{\circ} \mathrm{C}$ with $1.541 \mathrm{~g} / \mathrm{g}$. The overall lowest yield was determined aerobically at $25^{\circ} \mathrm{C}$ with $0.627 \mathrm{~g} / \mathrm{g}$. Yields determined for the genome reduced strain IIG-Bs20-5-1 were overall slightly lower than for strain JABs24, but in general surpassed the $Y_{\mathrm{P} / \mathrm{X}}$ of strain DSM $10^{\mathrm{T}}$. However, 


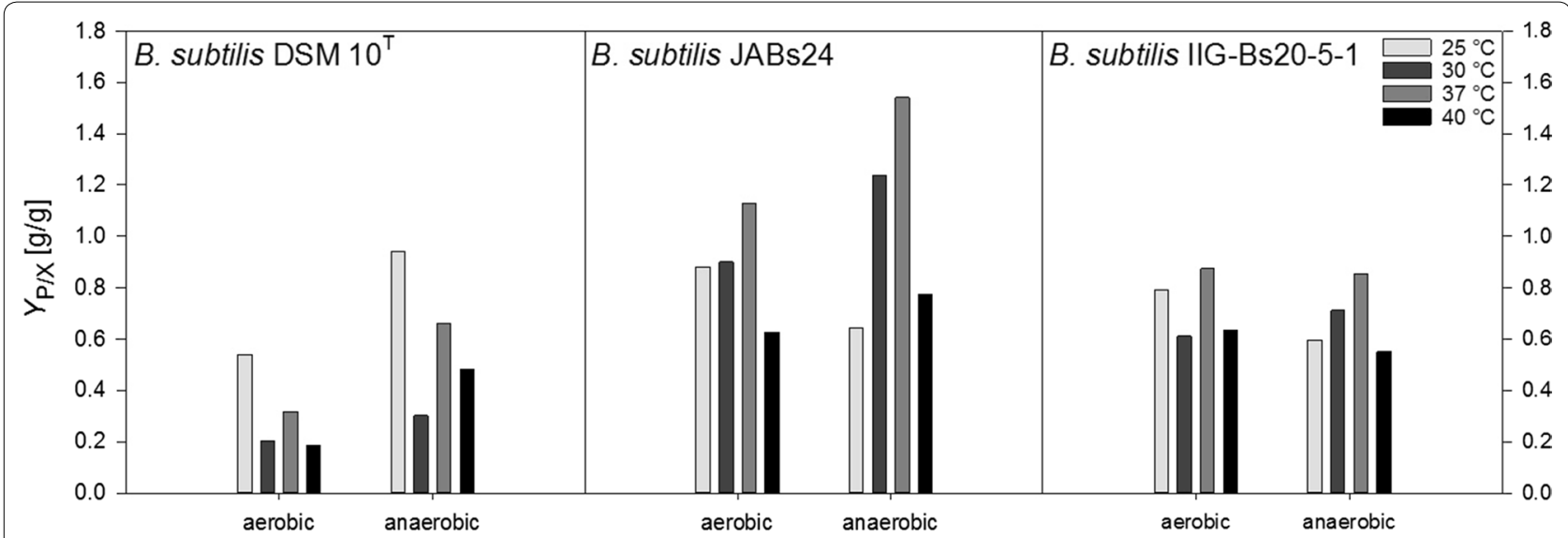

Fig. 6 Overview of the calculated product yields on biomass $Y_{P / X}(\mathrm{~g} / \mathrm{g})$ for strains B. subtilis DSM $10^{\top}$, B. subtilis JABs24 and B. subtilis $\| \mathrm{G}-\mathrm{Bs} 20-5-1$ under aerobic and anaerobic conditions at $25^{\circ} \mathrm{C}, 30^{\circ} \mathrm{C}, 37^{\circ} \mathrm{C}$ and $40^{\circ} \mathrm{C}$

other than for the two reference strains, differences in aerobic and anaerobic yields were not as significant and the $Y_{\mathrm{P} / \mathrm{X}}$ was mostly inferior under anaerobic conditions. For example, the $Y_{\mathrm{P} / \mathrm{X}}$ were 0.75 - to 0.97 -fold lower at $25^{\circ} \mathrm{C}, 37^{\circ} \mathrm{C}$ and at $40{ }^{\circ} \mathrm{C}$. At $30^{\circ} \mathrm{C}$, the $Y_{\mathrm{P} / \mathrm{X}}$ under aerobic and anaerobic conditions were $0.611 \mathrm{~g} / \mathrm{g}$ and $0.712 \mathrm{~g} / \mathrm{g}$, respectively. The overall highest $Y_{\mathrm{P} / \mathrm{X}}$ were obtained at $37^{\circ} \mathrm{C}$ with $0.873 \mathrm{~g} / \mathrm{g}$ and $0.854 \mathrm{~g} / \mathrm{g}$ for aerobic and anaerobic cultivations.

\section{Discussion}

The current research aimed at investigating the suitability of a genome reduced strain to produce surfactin. We hypothesized that the surfactin yields in strain $B$. subtilis IIG-Bs20-5-1 benefit from the employed genome reduction, and that the strain shows a similar growth pattern than the primary reference strain JABs24.

\section{Evaluation of growth, surfactin synthesis and yields obtained under the conditions tested}

The growth behavior of strains $168 s f p^{0}$ and DSM $10^{\mathrm{T}}$ was reported to be similar by Kabisch et al. (2013) and Julkowska et al. (2005). For specific growth rates, both strains yielded $\sim 0.4501 / \mathrm{h}$ (Kabisch et al. 2013), and strain BBG258, a $168 s f p^{+}$derivative, yielded $0.4991 / \mathrm{h}$ in a study conducted by Dhali et al. (2017). However, although the aerobic growth rates obtained within this study were much lower with $<0.2341 / \mathrm{h}$, it must be noted that strain 168 varies between laboratories due to domestication, and DSM $10^{\mathrm{T}}$ is reported to have different variants as well, such as ATCC 6051 (Kabisch et al. 2013) and NCBI 3610 (Julkowska et al. 2005). Hence, the assignment remains a challenge and comparisons are hindered (Zeigler et al. 2008). Contrariwise to literature, considering the overall growth rates obtained within this study at
$30{ }^{\circ} \mathrm{C}, 37^{\circ} \mathrm{C}$ and $40{ }^{\circ} \mathrm{C}$, strain DSM $10^{\mathrm{T}}$ was superior to strain JABs24 under aerobic conditions. It might be that the restoration of $s f p$ led to a reduced growth rate, as secondary metabolites such as lipopeptides are thought to be metabolically demanding as they are synthesized by large non-ribosomal peptide synthetases (Fischbach and Walsh 2006). In addition, B. subtilis undergoes a complex machinery of cell differentiation with surfactin being an important signal molecule (López and Kolter 2010). Reestablishing of surfactin synthesis is expected to change the overall cellular differentiation process, as reported by Julkowska et al. (2005) where surfactin induced swarming of cells. Interestingly, under anaerobic conditions strain DSM $10^{\mathrm{T}}$ was inferior to JABs24 and the genome of JABs 24 hence might be able to better adapt to anaerobic conditions.

Next to the growth rate, data obtained for the surfactin concentrations for strains JABs24 (Ongena et al. 2007; Coutte et al. 2010) and DSM $10^{\mathrm{T}}$ (Willenbacher et al. 2015b), as well as for the anaerobic yields calculated for strain DSM $10^{\mathrm{T}}$ are well in accordance to literature (Willenbacher et al. 2015a). However, next to the genetic alterations of strains used in different studies, comparisons are also difficult when different media or process set-ups and parameter are used as in Willenbacher et al. (2014). In this study, strain DSM $10^{\mathrm{T}}$ was cultivated in a $2.5 \mathrm{~L}$ benchtop bioreactor under aerobic conditions with surfactin recovery employing foam fractionation. $Y_{\mathrm{P} / \mathrm{X}}, Y_{\mathrm{X} / \mathrm{S}}$ and $Y_{\mathrm{P} / \mathrm{S}}$ obtained were $0.192 \mathrm{~g} / \mathrm{g}, 0.268 \mathrm{~g} / \mathrm{g}$ and $0.052 \mathrm{~g} / \mathrm{g}$. In the current study, at $30{ }^{\circ} \mathrm{C}$, the $Y_{\mathrm{P} / \mathrm{X}}$ was in a similar range with $0.204 \mathrm{~g} / \mathrm{g}$, and both $Y_{\mathrm{X} / \mathrm{S}}$ and $Y_{\mathrm{P} / \mathrm{S}}$ were much lower with $0.158 \mathrm{~g} / \mathrm{g}$ and $0.017 \mathrm{~g} / \mathrm{g}$, respectively.

Also with respect to the temperature, different strains, media and parameter used make it difficult to draw meaningful conclusions. Nevertheless, within this study, 
$37{ }^{\circ} \mathrm{C}$ was overall superior for all parameter tested and amongst the strains cultivated, which is well in accordance to different literature (Sen and Swaminathan 1997; Rahman and Ano 2009; Ghribi et al. 2012; Meena et al. 2018).

Davis et al. (1999) examined different batch cultures and reported that the highest $Y_{\mathrm{P} / \mathrm{X}}$ was obtained under nitrate-limited oxygen-depleted conditions with $0.075 \mathrm{~g} / \mathrm{g}$. In comparison, aerobic nitrogen-limited conditions yielded only $0.021 \mathrm{~g} / \mathrm{g}$. However, although the current results also indicated that, regardless nitrogenlimitation, anaerobic cultivations yielded higher $Y_{\mathrm{P} / \mathrm{X}}$, literature often reports that surfactin production is favored at good oxygenation (Yeh et al. 2006; Abdel-Mawgoud et al. 2008; Fahim et al. 2012; Ha et al. 2018). Although the $Y_{\mathrm{P} / \mathrm{X}}$ is often not calculated, data presented by AbdelMawgoud et al. (2008) also indicated that the $Y_{\mathrm{P} / \mathrm{X}}$ is increased at higher aeration in a medium containing only nitrate as sole nitrogen source. In the current study the $Y_{\mathrm{P} / \mathrm{X}}$ was generally superior under anaerobic conditions, but it has to be further elucidated which mechanisms are causing this effect. For example, the presence of nitrate itself and the concomitant nitrate respiration might result in the overall higher $Y_{\mathrm{P} / \mathrm{X}}$. As B. subtilis is also able to grow aerobically on nitrate as sole nitrogen source, further studies are desirable to evaluate the effect of the nitrogen source nitrate, especially as $B$. subtilis contains two nitrate reductases, with NasBC being active both aerobically and anaerobically in the assimilatory pathway, and NarGHJ being only induced anaerobically in the presence of the alternative electron acceptor nitrate (Nakano et al. 1998; Ye et al. 2000).

To sum up, the results obtained within the current study are comparably reliable and especially the high $Y_{\mathrm{P} / \mathrm{X}}$ of $1.127 \mathrm{~g} / \mathrm{g}$ and $1.541 \mathrm{~g} / \mathrm{g}$ obtained for strain JABs24 under both aerobic and anaerobic conditions at $37{ }^{\circ} \mathrm{C}$ must be emphasized which surpasses many reported $Y_{\mathrm{P} / \mathrm{X}}$ in literature for different process set-ups (Davis et al. 1999; Chtioui et al. 2012; Willenbacher et al. 2014, 2015a; Coutte et al. 2015; Dhali et al. 2017). Coutte et al. (2010) also reached a high $Y_{\mathrm{P} / \mathrm{X}}$ of $1.08 \mathrm{~g} / \mathrm{g}$ in a $168 s f p^{+}$derivative strain, but it has to be pointed out that a functional sfp from B. subtilis ATCC 21332 was integrated instead of restoration of the original $s f p$ as performed in this study. In this sense, with the $Y_{\mathrm{P} / \mathrm{X}}$ being superior for strain JABs24, the most crucial question is now, if the genome reduction led to a benefit as hypothesized.

\section{Strains JABs24 vs. IIG-Bs20-5-1-evaluation of the effect of genome reduction}

Constructing genome reduced strains is an interesting technique. The designed strains ideally show a similar or even better growth behavior than the parental strain
(Choe et al. 2016). In addition, when a strain shall be used as catalyst for the synthesis of a specific product, genome reduced strains are expected to yield higher titers as the deletion of non-essential genes saves metabolic resources (Choe et al. 2016). In 2008, the suitability of genome reduced $B$. subtilis with the aim of producing a target product was reported by Morimoto et al. (2008). However, the product used within that study was synthesized from a plasmid carrying the respective gene. In the current study, the target product surfactin is naturally produced by $B$. subtilis and the synthesis is based on a complex quorum sensing system (Hamoen 2003). Dhali et al. (2017) reported an increase in surfactin yield from $527 \pm 80$ to $1556 \pm 123 \mathrm{mg} / \mathrm{g}$ CDW by deleting the gene encoding for CodY in a $168 s f p^{+}$derivative. In our study, we expected an increase in surfactin synthesis as, for example, (i) the gene pps, which encodes for the large non-ribosomal peptide synthetase of the lipopeptide plipastatin was deleted and the cell can hence save resources, (ii) sporulation factors were deleted which influence cell differentiation and a higher ratio of cells might become surfactin producers, (iii) prophages were deleted which is expected to, amongst others, reduce the formation of autolysins and hence cell lysis.

A strain with several identical deletions was constructed by Westers (2003) and they reported that the strain possessing a $7.7 \%$ smaller genome exhibited a comparable growth behavior and biomass yield on substrate under laboratory conditions as the reference strain. However, they also pointed out that the suitability of their constructed genome reduced strain as bacterial cell factory remains open. In our study, the genome reduced strain IIG-Bs20-5-1 yielded either similar or even higher $\mathrm{CDW}_{\max }$, but especially under anaerobic conditions, the time of cultivation to reach $\mathrm{CDW}_{\max }$ was shorter than for strain JABs24. This observation is further on reflected in the determined growth rate $\mu$, which is overall both aerobically and anaerobically higher for strain IIG-Bs20-5-1. The $Y_{\mathrm{X} / \mathrm{S}}$ of strain IIG-Bs20-5-1 also surpassed the respective yields of strain JABs24 at almost all conditions tested, indicating a better conversion efficiency from glucose into biomass. Comparing the data for the growth rate $\mu$, $Y_{\mathrm{X} / \mathrm{S}}$ and the time to reach $\mathrm{CDW}_{\max }$ of strain JABs24 and IIG-Bs20-5-1, it gives the idea that the employed genome reduction has a higher positive impact especially under anaerobic conditions and at $37^{\circ} \mathrm{C}$. However, the better growth and the obtained higher biomass did not lead to higher surfactin concentrations and product yields per biomass $Y_{\mathrm{P} / \mathrm{X}}$. In both parameter, strain JABs24 was superior. With some exceptions, aerobically at $30{ }^{\circ} \mathrm{C}$ and $40{ }^{\circ} \mathrm{C}$, and anaerobically at $40{ }^{\circ} \mathrm{C}$, strain IIG-Bs20-5-1 yielded higher surfactin concentrations at $\mathrm{CDW}_{\max }$. However, apart from the surfactin concentration at 
$\mathrm{CDW}_{\max }$, the overall surfactin $\max _{\text {mas }}$ wigher for JABs24 throughout all experiments. The $Y_{\mathrm{P} / \mathrm{X}}$ for strain JABs24 was beyond that generally higher under anaerobic conditions, which is well in accordance to the observations from Willenbacher et al. (2015a). Interestingly, the $Y_{\mathrm{P} / \mathrm{X}}$ was in a similar range for strain IIG-Bs20-5-1 under aerobic and anaerobic conditions at the respective temperatures, indicating that the genome reduction has a rather negative effect on the surfactin synthesis under anaerobic conditions. In this context, the employed genome reduction led to improved growth rates and $Y_{\mathrm{X} / \mathrm{S}}$, but did neither positively influence the surfactin synthesis nor productivity, nor the yields $Y_{\mathrm{P} / \mathrm{S}}$ and $Y_{\mathrm{P} / \mathrm{X}}$.

To sum up, aerobic cultivations were superior with respect to $\mu, Y_{\mathrm{X} / \mathrm{S}}$ and $Y_{\mathrm{P} / \mathrm{S}}$, while anaerobic cultivations overall yielded better $Y_{\mathrm{P} / \mathrm{X}}$, especially for strain JABs 24 . In comparison to the reported high surfactin producing wild-type DSM $10^{\mathrm{T}}$, both strain JABs24 as well as the genome reduced strain IIG-Bs20-5-1 reached excellent values for surfactin concentration and $Y_{\mathrm{P} / \mathrm{X}}$. In direct comparison, the genome reduced strain was superior to its main reference strain with respect to both the growth rate $\mu$ and $Y_{\mathrm{X} / \mathrm{S}}$. Anaerobic conditions furthermore favored the growth and conversion from glucose into biomass for IIG-Bs20-5-1 compared to strain JABs24, however, the surfactin synthesis was negatively affected anaerobically. Although hypothesized that the genome reduced strain leads to better surfactin yields, strain JABs24 reached outstanding surfactin concentrations aerobically and $Y_{\mathrm{P} / \mathrm{X}}$ values anaerobically.

\section{Additional file}

Additional file 1: Table S1. Plasmids used in this study. Table S2. Oligonucleotides used in this study. Table S3. Strains used in this study.

\section{Acknowledgements}

The authors thank Annette Schneck (University of Stuttgart, Institute of Industrial Genetics) for technical assistance.

\begin{abstract}
Authors' contributions
MG planned and executed the experiments, collected data, created the graphs and drafted the manuscript. IK performed part of the experiments and collected and evaluated corresponding data. $\mathrm{KMH}$ and JA constructed the strains and contributed to interpretation of the experiments. $\mathrm{MH}$ significantly contributed to conception and design of the study and interpretation of the experiments. RH substantially contributed to conception and design of the conducted experiments. All authors read and approved the final manuscript.
\end{abstract}

\section{Funding}

This study was financially supported by the German Research Foundation (DFG), Project Number 365166982.

\section{Availability of data and materials}

Data relevant to this study which is not included in the manuscript is available as additional file. Please turn to the corresponding author for all other requests.

\section{Ethics approval and consent to participate}

Not applicable.

\section{Consent for publication \\ Not applicable.}

\section{Competing interests}

The authors declare that they have no competing interests.

\section{Author details}

${ }^{1}$ Department of Bioprocess Engineering (150k), Institute of Food Science and Biotechnology (150), University of Hohenheim, Fruwirthstr. 12, 70599 Stuttgart, Germany. ${ }^{2}$ Institute of Industrial Genetics, University of Stuttgart, Allmandring 31, 70569 Stuttgart, Germany.

Received: 28 April 2019 Accepted: 5 June 2019

Published online: 12 June 2019

\section{References}

Abdel-Mawgoud AM, Aboulwafa MM, Hassouna NA-H (2008) Optimization of surfactin production by Bacillus subtilis isolate BS5. Appl Biochem Biotechnol 150:305-325

Alonso S, Martin PJ (2016) Impact of foaming on surfactin production by BacilIus subtilis: implications on the development of integrated in situ foam fractionation removal systems. Biochem Eng J 110:125-133

Ara K, Ozaki K, Nakamura K, Yamane K, Sekiguchi J, Ogasawara N (2007) Bacillus minimum genome factory: effective utilization of microbial genome information. Biotechnol Appl Biochem 46:169-178

Barbe V, Cruveiller S, Kunst F, Lenoble P, Meurice G, Sekowska A, Vallenet D, Wang T, Moszer I, Medigue C, Danchin A (2009) From a consortium sequence to a unified sequence: the Bacillus subtilis 168 reference genome a decade later. Microbiology 155:1758-1775

Choe D, Cho S, Kim SC, Cho B-K (2016) Minimal genome: worthwhile or worthless efforts toward being smaller? Biotechnol J 11:199-211

Chtioui O, Dimitrov K, Gancel F, Dhulster P, Nikov I (2012) Rotating discs bioreactor, a new tool for lipopeptides production. Process Biochem 47:2020-2024

Coutte F, Leclère V, Béchet M, Guez J-S, Lecouturier D, Chollet-Imbert M, Dhulster P, Jacques P (2010) Effect of pps disruption and constitutive expression of srfA on surfactin productivity, spreading and antagonistic properties of Bacillus subtilis 168 derivatives. J Appl Microbiol 109:480-491

Coutte F, Lecouturier D, Leclère V, Béchet M, Jacques P, Dhulster P (2013) New integrated bioprocess for the continuous production, extraction and purification of lipopeptides produced by Bacillus subtilis in membrane bioreactor. Process Biochem 48:25-32

Coutte F, Niehren J, Dhali D, John M, Versari C, Jacques P (2015) Modeling leucine's metabolic pathway and knockout prediction improving the production of surfactin, a biosurfactant from Bacillus subtilis. Biotechnol J 10:1216-1234

Davis D, Lynch H, Varley J (1999) The production of surfactin in batch culture by Bacillus subtilis ATCC 21332 is strongly influenced by the conditions of nitrogen metabolism. Enzyme Microb Technol 25:322-329

Dhali D, Coutte F, Arias AA, Auger S, Bidnenko V, Chataigné G, Lalk M, Niehren J, de Sousa J, Versari C, Jacques P (2017) Genetic engineering of the branched fatty acid metabolic pathway of Bacillus subtilis for the overproduction of surfactin $C_{14}$ isoform. Biotechnol J 12(1600574):1-10

Fahim S, Dimitrov K, Gancel F, Vauchel P, Jacques P, Nikov I (2012) Impact of energy supply and oxygen transfer on selective lipopeptide production by Bacillus subtilis BBG21. Bioresour Technol 126:1-6

Fischbach MA, Walsh CT (2006) Assembly-line enzymology for polyketide and nonribosomal peptide antibiotics: logic, machinery, and mechanisms. Chem Rev 106:3468-3496

Freitas de Oliveira DW, Lima França ÍW, Nogueira Félix AK, Lima Martins JJ, Aparecida Giro ME, Melo VMM, Gonçalves LRB (2013) Kinetic study of 
biosurfactant production by Bacillus subtilis LAMI005 grown in clarified cashew apple juice. Colloids Surf B 101:34-43

Geissler M, Oellig C, Moss K, Schwack W, Henkel M, Hausmann R (2017) Highperformance thin-layer chromatography (HPTLC) for the simultaneous quantification of the cyclic lipopeptides surfactin, iturin $A$ and fengycin in culture samples of Bacillus species. J Chromatogr B 1044-1045:214-224

Geissler M, Morabbi Heravi K, Henkel M, Hausmann R (2019) Lipopeptide biosurfactants from Bacillus species. In: Hayes D, Solaiman DK, Ashby RD (eds) Biobased surfactants: synthesis, properties, and applications, 2nd edn. Elsevier Science, London

Ghribi D, Abdelkefi-Mesrati L, Mnif I, Kammoun R, Ayadi I, Saadaoui I, Maktouf S, Chaabouni-Ellouze S (2012) Investigation of antimicrobial activity and statistical optimization of Bacillus subtilis SPB1 biosurfactant production in solid-state fermentation. J Biomed Biotechnol 2012:1-12

Green MR, Sambrook J (2012) Molecular cloning: a laboratory manual, 4th edn. Cold Spring Harbor Laboratory Press, Cold Spring Harbor

Gudiña EJ, Fernandes EC, Rodrigues AI, Teixeira JA, Rodrigues LR (2015) Biosurfactant production by Bacillus subtilis using corn steep liquor as culture medium. Front Microbiol 6(59):1-7

Ha S, Kim H, Chun H, Hwang I, Lee J-H, Kim J-C, Kim I, Park H (2018) Effect of oxygen supply on surfactin production and sporulation in submerged culture of Bacillus subtilis Y9. Appl Sci 8(1660):1-10

Hamoen LW (2003) Controlling competence in Bacillus subtilis: shared use of regulators. Microbiology 149:9-17

Harwood CR, Cutting SM (1990) Molecular biological methods for Bacillus. Wiley, Chichester

Julkowska D, Obuchowski M, Holland IB, Seror SJ (2005) Comparative analysis of the development of swarming communities of Bacillus subtilis 168 and a natural wild type: critical effects of surfactin and the composition of the medium. J Bacteriol 187:65-76

Kabisch J, Thürmer A, Hübel T, Popper L, Daniel R, Schweder T (2013) Characterization and optimization of Bacillus subtilis ATCC 6051 as an expression host. J Biotechnol 163:97-104

Kobayashi K, Ehrlich SD, Albertini A, Amati G, Andersen KK, Arnaud M, Asai K, Ashikaga S, Aymerich S, Bessieres P, Boland F, Brignell SC, Bron S, Bunai K, Chapuis J, Christiansen LC, Danchin A, Debarbouille M, Dervyn E, Deuerling E, Devine K, Devine SK, Dreesen O, Errington J, Fillinger S, Foster SJ, Fujita Y, Galizzi A, Gardan R, Eschevins C, Fukushima T, Haga K, Harwood CR, Hecker M, Hosoya D, Hullo MF, Kakeshita H, Karamata D, Kasahara Y, Kawamura F, Koga K, Koski P, Kuwana R, Imamura D, Ishimaru M, Ishikawa S, Ishio I, Le Coq D, Masson A, Mauel C, Meima R, Mellado RP, Moir A, Moriya S, Nagakawa E, Nanamiya H, Nakai S, Nygaard P, Ogura M, Ohanan T, O'Reilly M, O'Rourke M, Pragai Z, Pooley HM, Rapoport G, Rawlins JP, Rivas LA, Rivolta C, Sadaie A, Sadaie Y, Sarvas M, Sato T, Saxild HH, Scanlan E, Schumann W, Seegers JFML, Sekiguchi J, Sekowska A, Seror SJ, Simon M, Stragier P, Studer R, Takamatsu H, Tanaka T, Takeuchi M, Thomaides HB, Vagner V, van Dijl JM, Watabe K, Wipat A, Yamamoto H, Yamamoto M, Yamamoto Y, Yamane K, Yata K, Yoshida K, Yoshikawa H, Zuber U, Ogasawara N (2003) Essential Bacillus subtilis genes. Proc Natl Acad Sci 100:4678-4683

Koonin EV (2000) HOW many genes can make a cell: the minimal-gene-set concept. Annu Rev Genomics Hum Genet 1:99-116

Kunst F, Ogasawara N, Moszer I, Albertini AM, Alloni G, Azevedo V, Bertero MG, Bessières $P$, Bolotin A, Borchert S, Borriss R, Boursier L, Brans A, Braun M, Brignell SC, Bron S, Brouillet S, Bruschi CV, Caldwell B, Capuano V, Carter NM, Choi S-K, Codani J-J, Connerton IF, Cummings NJ, Daniel RA, Denizot F, Devine KM, Düsterhöft A, Ehrlich SD, Emmerson PT, Entian KD, Errington J, Fabret C, Ferrari E, Foulger D, Fritz C, Fujita M, Fujita Y, Fuma S, Galizzi A, Galleron N, Ghim S-Y, Glaser P, Goffeau A, Golightly EJ, Grandi G, Guiseppi G, Guy BJ, Haga K, Haiech J, Harwood CR, Hénaut A, Hilbert H, Holsappel S, Hosono S, Hullo M-F, Itaya M, Jones L, Joris B, Karamata D, Kasahara Y, Klaerr-Blanchard M, Klein C, Kobayashi Y, Koetter P, Koningstein G, Krogh S, Kumano M, Kurita K, Lapidus A, Lardinois S, Lauber J, Lazarevic V, Lee S-M, Levine A, Liu H, Masuda S, Mauël C, Médigue C, Medina N, Mellado RP, Mizuno M, Moestl D, Nakai S, Noback M, Noone D, O'Reilly M, Ogawa K, Ogiwara A, Oudega B, Park S-H, Parro V, Pohl TM, Portetelle D, Porwollik S, Prescott AM, Presecan E, Pujic P, Purnelle B, Rapoport G, Rey M, Reynolds S, Rieger M, Rivolta C, Rocha E, Roche B, Rose M, Sadaie Y, Sato T, Scanlan E, Schleich S, Schroeter R, Scoffone F, Sekiguchi J, Sekowska A, Seror SJ, Serror P, Shin B-S, Soldo B, Sorokin A, Tacconi E, Takagi T, Takahashi H, Takemaru K, Takeuchi M, Tamakoshi A, Tanaka
T, Terpstra P, Tognoni A, Tosato V, Uchiyama S, Vandenbol M, Vannier F, Vassarotti A, Viari A, Wambutt R, Wedler E, Wedler H, Weitzenegger T, Winters P, Wipat A, Yamamoto H, Yamane K, Yasumoto K, Yata K, Yoshida K, Yoshikawa H-F, Zumstein E, Yoshikawa H, Danchin A (1997) The complete genome sequence of the Gram-positive bacterium Bacillus subtilis. Nature 390:249-256

López D, Kolter R (2010) Extracellular signals that define distinct and coexisting cell fates in Bacillus subtilis. FEMS Microbiol Rev 34:134-149

Meena KR, Sharma A, Kumar R, Kanwar SS (2018) Two factor at a time approach by response surface methodology to aggrandize the Bacillus subtilis KLP2015 surfactin lipopeptide to use as antifungal agent. J King Saud Univ Sci. https://doi.org/10.1016/j.jksus.2018.05.025

Morabbi Heravi K, Altenbuchner J (2018) Cross talk among transporters of the phosphoenolpyruvate-dependent phosphotransferase system in Bacillus subtilis. J Bacteriol 200(19):1-18

Morimoto T, Kadoya R, Endo K, Tohata M, Sawada K, Liu S, Ozawa T, Kodama T, Kakeshita H, Kageyama Y, Manabe K, Kanaya S, Ara K, Ozaki K, Ogasawara N (2008) Enhanced recombinant protein productivity by genome reduction in Bacillus subtilis. DNA Res 15:73-81

Motejadded H, Altenbuchner J (2007) Integration of a lipase gene into the Bacillus subtilis chromosome: recombinant strains without antibiotic resistance marker. Iran J Biotechnol 5(2):105-109

Nakano MM, Hoffmann T, Zhu Y, Jahn D (1998) Nitrogen and oxygen regulation of Bacillus subtilis nasDEF encoding NADH-dependent nitrite reductase by TrrA and ResDE. J Bacteriol 180(20):5344-5350

Ongena M, Jourdan E, Adam A, Paquot M, Brans A, Joris B, Arpigny J-L, Thonart P (2007) Surfactin and fengycin lipopeptides of Bacillus subtilis as elicitors of induced systemic resistance in plants. Environ Microbiol 9:1084-1090

Rahman MS, Ano T (2009) Production characteristics of lipopeptide antibiotics in biofilm fermentation of Bacillus subtilis. J Environ Sci 21:S36-S39

Rahmer R, Morabbi Heravi K, Altenbuchner J (2015) Construction of a supercompetent Bacillus subtilis 168 using the $P_{m t A}$-comKS inducible cassette. Front Microbiol 6(1431):1-11

Reuß DR, Altenbuchner J, Mäder U, Rath H, Ischebeck T, Sappa PK, Thürmer A, Guérin C, Nicolas P, Steil L, Zhu B, Feussner I, Klumpp S, Daniel R, Commichau FM, Völker U, Stülke J (2017) Large-scale reduction of the Bacillus subtilis genome: consequences for the transcriptional network, resource allocation, and metabolism. Genome Res 27:289-299

Sen R, Swaminathan T (1997) Application of response-surface methodology to evaluate the optimum environmental conditions for the enhanced production of surfactin. Appl Microbiol Biotechnol 47:358-363

Singh R, Kumar M, Mittal A, Mehta PK (2017) Microbial metabolites in nutrition, healthcare and agriculture. 3 Biotech 7(15):1-14

van Dijl JM, Hecker M (2013) Bacillus subtilis: from soil bacterium to supersecreting cell factory. Microb Cell Fact 12(3):1-6

Wenzel M, Altenbuchner J (2015) Development of a markerless gene deletion system for Bacillus subtilis based on the mannose phosphoenolpyruvatedependent phosphotransferase system. Microbiology 161:1942-1949

Westers H (2003) Genome engineering reveals large dispensable regions in Bacillus subtilis. Mol Biol Evol 20:2076-2090

Willenbacher J, Zwick M, Mohr T, Schmid F, Syldatk C, Hausmann R (2014) Evaluation of different Bacillus strains in respect of their ability to produce Surfactin in a model fermentation process with integrated foam fractionation. Appl Microbiol Biotechnol 98:9623-9632

Willenbacher J, Rau J-T, Rogalla J, Syldatk C, Hausmann R (2015a) Foam-free production of Surfactin via anaerobic fermentation of Bacillus subtilis DSM 10'. AMB Express 5(21):1-9

Willenbacher J, Yeremchuk W, Mohr T, Syldatk C, Hausmann R (2015b) Enhancement of Surfactin yield by improving the medium composition and fermentation process. AMB Express 5(57):1-9

Willenbacher J, Mohr T, Henkel M, Gebhard S, Mascher T, Syldatk C, Hausmann $R$ (2016) Substitution of the native srfA promoter by constitutive $P_{\text {veg }}$ in two B. subtilis strains and evaluation of the effect on surfactin production. J Biotechnol 224:14-17

Yanisch-Perron C, Vieira J, Messing J (1985) Improved MI3 phage cloning vectors and host strains: nucleotide sequences of the M13mp18 and pUC19 vectors. Gene 33:103-119

Ye RW, Tao W, Bedzyk L, Young T, Chen M, Li L (2000) Global gene expression profiles of Bacillus subtilis grown under anaerobic conditions. J Bacteriol 182:4458-4465 
Yeh M-S, Wei Y-H, Chang J-S (2006) Bioreactor design for enhanced carrierassisted surfactin production with Bacillus subtilis. Process Biochem 41:1799-1805

Zeigler DR, Pragai Z, Rodriguez S, Chevreux B, Muffler A, Albert T, Bai R, Wyss M, Perkins JB (2008) The origins of 168, W23, and other Bacillus subtilis legacy strains. J Bacteriol 190:6983-6995

\section{Publisher's Note}

Springer Nature remains neutral with regard to jurisdictional claims in published maps and institutional affiliations.
Submit your manuscript to a SpringerOpen ${ }^{\circ}$ journal and benefit from:

- Convenient online submission

- Rigorous peer review

- Open access: articles freely available online

- High visibility within the field

- Retaining the copyright to your article

Submit your next manuscript at $\boldsymbol{\nabla}$ springeropen.com 